\title{
Intervention and non-intervention in international political theory
}

Contrary to international law, international political theory and political philosophy paid scant attention to the ethics of intervention in the long nineteenth century. ${ }^{1}$ As for humanitarian intervention per se, there is nothing, apart from cursory remarks by John Stuart Mill and Giuseppe Mazzini. On the wider question of intervention and non-intervention we will refer to their views and to those of Kant, Hegel and Cobden.

Based on today's distinction between cosmopolitanism and communitarianism one would expect that cosmopolitans would be inclined towards intervention for humanitarian and other principled reasons, while communitarians would adhere to non-intervention. ${ }^{2}$ Yet Kant, regarded as the father of modern cosmopolitanism, ${ }^{3}$ is, prima facie, against intervention. Cobden, a cosmopolitan, is rigidly against any notion of intervention. Mazzini, a communitarian (though with a cosmopolitan bent) is a cautious supporter of intervention. J. S. Mill, arguably a communitarian, ${ }^{4}$ places himself gingerly between non-intervention and intervention. Only Hegel, perhaps the father of the communitarian approach, ${ }^{5}$ does not defy expectations, advocating non-intervention but inadvertently bringing military intervention in by pointing to war's positive aspects.

\section{Kant, non-intervention and republicanism}

Kant, the advocate of a cosmopolitan existence, of a cosmopolitan confederation of republican states and of universal human rights, ${ }^{6}$ has very little to say about intervention and does not refer at all to intervention for humanitarian reasons. In Preliminary Article 5 of his celebrated essay Toward Perpetual Peace: A Philosophical Sketch (1795), ${ }^{8}$ it is stipulated that 'No State Shall by Force Interfere with the Constitution or Government of Another State'. And he makes two points: (1) there is a problem over who is to authorize interference, since there is no higher authority; and (2) if a state has fallen into 'evil', 'its lawlessness should serve as a warning. ${ }^{9}$ And he comes up with only one exception to non-intervention: ${ }^{10}$ 
if a state, through internal discord, should split into two parts, each ... laying claim to the whole; in that case a foreign state could not be charged with interfering in the constitution of another state if it gave assistance to one of them (for this is anarchy).

He cautions that prior to this critical phase, such interference would amount to 'a violation of the right of a people', making 'the autonomy of all states insecure. ${ }^{11}$ Only when a state has collapsed into anarchy, with rival groups claiming sovereign authority, can other states intervene to assist in bringing about an end to the anarchy. ${ }^{12}$ Surprisingly, Kant (like Grotius) was opposed to revolution against oppression, ${ }^{13}$ despite his great enthusiasm for the French Revolution, the American Revolution and the Irish struggle, a contradictory position that has baffled scholars ever since. ${ }^{14}$

Kant does not address intervention in any other work and it is clear that he does not suggest any right or duty of humanitarian intervention ${ }^{15}$ or intervention to promote 'republicanism'. ${ }^{16} \mathrm{His}$ position on intervention is not unrelated to his position on war. For the German philosopher, war is 'the scourge of mankind', 'the destroyer of everything good ${ }^{17}$ and 'creates more evil than it destroys'. ${ }^{18}$ Yet strictly speaking he was no pacifist. ${ }^{19} \mathrm{He}$ was critical of 'a long peace' in some cases $^{20}$ and regarded the historical emergence of civil society as the result of violent means and war, which unified people under a general will. ${ }^{21}$ On the whole, a justified war was defensive: to defend one's country and repulse aggression, which could also include 'anticipatory attack'. ${ }^{22}$ But as regards military intervention, he was more than clear: intervention even for ethical reasons introduces a right to war, with a disastrous effect on the attempt to ban war. ${ }^{23}$

Despite the prohibition set out in Preliminary Article 5, several scholars have tried to prove that he did not reject intervention or humanitarian intervention. There are three main positions: (1) the view that Kant upholds a rigid principle of non-intervention $;^{24}(2)$ guarded assertion that had he been faced with or contemplated massive atrocities, he would have been more open to intervention qua humanitarian intervention; ${ }^{25}$ and (3) claims that he was in fact supportive of humanitarian intervention. ${ }^{26}$

One line of reasoning is to link Preliminary Article 5 with Kant's First Definite Article, which reads as follows: 'The Civil Constitution of Every State shall be Republican'. Republican states are peaceful internationally and base their internal policy on justice, the rule of law and respect for individual autonomy. ${ }^{27}$ From this ambit it has been argued that, assuming that the Definitive Articles are 'more basic' (in fact this is not the case, as Kantian scholars point out), non-intervention 'does not apply to forms of intervention that might promote or defend the development or survival of republican forms of government. ${ }^{28}$

John Vincent was of the view that 'Kant appeared to imply an exception to the rule of nonintervention if by intervention a republic could be established or a despotic regime crushed'. ${ }^{29}$ Along similar lines, Fernando Tesón maintains that 
Kant's 'nonintervention principle is dependent upon compliance with the First Definitive Article. Internal legitimacy based on respect for human rights and democracy is what gives states the shield of sovereignty against foreign intervention'. ${ }^{30}$ Consequently, 'nonintervention holds only among liberal states'. ${ }^{31}$ Harry van der Linden refers to Kant's concept of states as 'moral persons with autonomy' founded on 'the social contract' and 'united will'. On this basis he surmises that 'political intervention is only wrong with respect to republican states, or approximations thereof, and may be justified with regard to unjust states if it accords with the will of their people struggling for democracy'. ${ }^{32}$

Other Kantian scholars venture onto more controversial grounds. Thomas Hill for instance maintains that, according to Kant's logic, people in anarchy or 'a state of nature' can be forcefully made to join the legal order 'so long as it is reasonably certain that intervention is necessary and will be effective without further implications and effects that are morally unacceptable ${ }^{33}$ and concludes that in Kant's ethics 'there is no absolute prohibition of humanitarian intervention in all cases'. ${ }^{34}$ Antonio Franceschet admits that Kant has nothing explicit on humanitarian intervention, ${ }^{35}$ but claims that one can extrapolate from his work, if it is seen from its 'ethico-political reasoning within his broad roadmap for international reform' and 'legal evolution'. ${ }^{36}$ Accordingly, five themes provide a more comprehensive account of Kant regarding humanitarian intervention: (1) juridical pacifism; (2) institutionalization and constitutionalization; (3) the restructuring of the rights of war and peace; (4) the development of authorized coercion; and (5) cosmopolitan citizenship rights. ${ }^{37}$

It is hard to pass judgement on whether these authors interpret what Kant was all about or whether they present a different Kantian perspective and not Kant as such. As for Preliminary Article 5 being applicable only to republican states, in fact only the Definitive Articles refer exclusively to republican states; the Preliminary Articles refer to all states, republican or otherwise; ${ }^{38}$ and Kant 'nowhere makes any explicit claim regarding the priority of republicanism over nonintervention'. ${ }^{39}$ More generally, Kant wanted to deter states becoming paternalistic guardians of the well-being of other states. ${ }^{40}$

One is probably on safer grounds if one sticks to the letter of Kant. At least four points are worth making. First of all, Kant was guarded on intervention, not wanting to open a Pandora's box, given his views on war and peace, autonomy and morality. Secondly, he wrote Perpetual Peace in the wake of the French Revolution and apparently one of his main preoccupations was not to give grounds for foreign interventions against Republican France ${ }^{41}$ (as advocated, say, by Burke). Thirdly, Kant, as a cosmopolitan, was not an advocate of conquest and colonialism, and so did not want to bring the less fortunate non-Europeans into the European fold. ${ }^{42}$ Fourthly, even scholars critical of the extrapolations of others are prepared to offer a small opening for Kant's advocacy of intervention in extreme humanitarian instances. Pierre Laberge for instance has argued that ' $\mathrm{s}$ ] ince genocide 
is an idea that can scarcely have occurred to him, to hold that he would prohibit intervention even in such extreme circumstances is surely to be guilty of an anachronism'. ${ }^{43}$ Georg Cavallar is prepared to entertain that 'Kant might have favoured intervention to stop dramatic violations of human rights (for example genocide)'. ${ }^{44}$ Franceschet is predictably more forthright: 'The idea that a state that would commit or allow genocide or would otherwise deny its population their basic moral rights or humanity is not only inconceivable but conceptually impossible for Kant'. ${ }^{45}$ Howard Williams acknowledges the opening that may arise from Kant's support for universal human rights and 'a moral responsibility to be concerned about how citizens in other states are treated by their governments, ${ }^{46}$ but asserts that this does not lead to the 'active involvement of our government in attempting to redress or punish wrongs in other states. ${ }^{47}$ His conclusion is that only 'the breakdown of order' tantamount to civil war, with no sovereign power in control, permits intervention, provided that intervention has been requested by one of the warring sides, notably 'the party that would bring the disputed territory into the peaceful federation' ${ }^{48}$

\section{Hegel, non-intervention and war}

For Hegel, states, like persons, are autonomous in the moral sense and 'realize their nature in the choice and pursuit of ends' ${ }^{49}$ The state is 'ethical', 'the actuality of the ethical idea'. ${ }^{50}$ According to Hegel: 'The nation as state is mind in its substantive rationality and immediate actuality and is thus the absolute power on earth. It follows that every state is sovereign and autonomous against its neighbors' ${ }^{51}$

Tesón has called this reification of the state the 'Hegelian myth': that the state is 'a moral being, capable of making moral choices' and, as in the case of persons, whose moral choices deserve respect from others, 'state choices deserve respect from foreigners', hence ' $\mathrm{f}$ ] oreign intervention is a violation of that autonomy, even when it is undertaken for benign purposes.' ${ }^{52}$ Moreover, according to Tesón and others before him, such as Karl Popper, Hegel glorified war and even aggressive war in the name of 'vitality'. ${ }^{53} \mathrm{He}$ regarded war as one of the means 'by which the ethical character of the state is preserved'. ${ }^{54}$ According to Steven Smith, Hegel arrives at this conclusion on the basis of the following syllogism: 'The state is an ethical unity. 2) States frequently engage in war to preserve their unity. 3) Therefore war is a "moment" in the ethical life of the state'. ${ }^{55}$

For Hegel, war is outside the domain of ethics and not 'a matter of right meeting wrong, but rather a clash between two subjectively perceived rights'. ${ }^{56}$ As he put it: 'Each party claims to have right on its side; and both parties are right. It is just the rights themselves which have come into contradiction with one another' ${ }^{57} \mathrm{Hegel}$, anticipating the thinking of present-day conflict research, claims that disputes arise not as a result of 'real grievances as on subjective perception of an alleged threat posed'. ${ }^{58}$ 
These are valid points and hardly a glorification of war or militarism. But several other passages by Hegel are more extreme, such as the following: 'War is the moral health of peoples in their struggle against petrification.... Just as the breeze saves the sea from foulness, which is the result of continued complacency, so does war for people. ${ }^{59} \mathrm{He}$ also refers to the heroic and sacrifice aspects of war, to courage, honour and internal cooperation and regards perpetual peace $\dot{a}$ la Kant as an illusion. ${ }^{60}$

Hegel's glorification of war and presumed militarism have been challenged, starting with John Plamenatz and Schlomo Avineri, who present him as more nuanced and not an advocate of aggressive war. ${ }^{61}$ As is often the case with scholarly controversies, a fairer depiction is somewhere in the middle or is reached via another vantage point that makes the polar opposites less convincing. ${ }^{62}$ Apparently, several of Hegel's extreme statements were motivated by the German predicament of his time, characterized by fragmentation and lack of unity. ${ }^{63}$ And it is worth noting that wars were then quite different, with fewer casualties than the battles and wars that were to follow Hegel's death. ${ }^{64}$

\section{Cobden, peace, free trade and non-intervention}

Moving from the two great philosophers, Kant and Hegel, to Cobden may appear odd, but it is worth stressing that Cobden, though not a political philosopher, is regarded an important liberal thinker in his own right and one of the earliest exponents of the liberal internationalism in international relations. He is also regarded as a precursor of the theories of functionalism and interdependence. ${ }^{65}$

Cobden, the 'international man', ${ }^{66}$ as he was called during his lifetime, was as absolute as Hegel in his stance against intervention, though not for the same reasons, and he was more consistent, not bringing intervention in through the back door by presenting the positive functions of war.

For Cobden, freedom of commerce was essential for peace, a view shared by his close associate, John Bright. He was convinced that 'unfettered commerce would create such a powerful incentive for peace that men would prevent their governments from using war as the chosen instrument for serving their interests ${ }^{67}$ However, he was not an advocate of peace for the sake of free trade. ${ }^{68}$ If free trade conflicted with peace, as in the case of trade in armaments or loans for armament, he was against it ('No free trade in cutting throats', as he put it). ${ }^{69}$ As a committed exponent of progress brought about by industrialization and trade, he was strongly opposed to militarism, arms expenditures, colonial expansion and imperialism. ${ }^{70}$

It is within this context that Cobden was an advocate of 'an absolute policy of nonintervention'. ${ }^{71}$ As he put it: 'I am against any interference by the government of any country in the affairs of another nation, even if it is confined to moral suasion. ${ }^{\text {' }}$ Non-intervention was 'a necessary, if not sufficient condition for 
international peace, ${ }^{73}$ and could be more readily associated with interests than with a vague vision of future peace. He scathingly criticized great power intervention, even for noble goals. ${ }^{74}$ The regeneration of a people could come about only by the 'force and virtue of native elements, and without assistance of any kind'. ${ }^{75}$ Anticipating J. S. Mill (see below) he maintained that a 'people which wants a saviour' and 'which does not possess an earnest and pledge of freedom in its own heart, is not yet ready to be free' ${ }^{76}$

According to Vincent's reading of Cobden, 'intervention was doubly inappropriate as a means of promoting liberalism abroad; outside assistance could not promote a necessarily mature growth, and if such assistance were requested by a people, that very request was evidence of its immaturity and inability to benefit from intervention'. ${ }^{77}$ Cobden could accept counter-intervention only as a means of upholding the principle of non-intervention, and the only sanctions he could accept were 'the power of opinion and moral force' ${ }^{78}$ His condemnation of intervention had as its primary target British foreign policy under the sway of Palmerston, whose interventionism, according to Cobden, was against the interests of the British people. ${ }^{79}$ The fact that the 'international man' was also a pacifist activist ${ }^{80}$ made his absolute principle of non-intervention more convincing. ${ }^{81}$ Moreover, Cobden was consistent in his anti-interventionism cum anti-imperialism, contrary to other British liberals who were 'more selective,, ${ }^{82}$ as in the case of James Mill and John Stuart Mill. ${ }^{83}$

\section{Mazzini, nationality and non-intervention/intervention}

Mazzini, like Cobden, was not a political philosopher, but a politician and activist. He is known today as the 'Beating Heart of Italy', the foremost inspirer of Italian unification. But in his lifetime he was one of the most respected theorists of democracy and of the principle of nationality (national self-determination), with considerable international influence.

Mazzini's views on nationalism were moderate and liberal, and though famous as a prophet of nationalism, 'humanity' is his keyword rather than 'nationality'. ${ }^{84}$ For Mazzini, the starting point is the individual. Individuals fulfil themselves in the nation and the nation fulfils itself in humanity, while the idea of cosmopolitanism left out this essential middle link (i.e. the nation). ${ }^{85}$ As in the case of Herder, he regarded all European nations as equal, each with its own mission in the world. He was basically a democratic patriot and not a nationalist, and sincerely believed that independent democratic nations (states corresponding to a nation) would be peaceful in their relations. Thus Mazzini can be seen as an advocate of 'democratic peace' on a par with Kant (democracies are peaceful at the inter-state level) and, as with Cobden, as one of the pioneers of liberal internationalism. ${ }^{86}$

As did both Cobden and J. S. Mill, Mazzini maintained that foreign intervention was not warranted in domestic political struggles for democratic rule and 
national liberation. But certain factors made him temper his views and part ways with Cobden, bringing him much closer to Mill (see below), with whom he was personally acquainted (and they respected each other's views).

Mazzini's views on intervention appear mainly in a succinct essay entitled 'On Nonintervention', written in 1851, mostly for a British audience (Mazzini lived in London for more than thirty years) ${ }^{87} \mathrm{He}$ argued that adherence to nonintervention had to apply if two preconditions were met. Firstly, it was applicable if it was adhered to absolutely by all states. But this was hardly ever the case, as despotic states intervened to help other despotic states threatened by revolutions or national liberation movements, contradicting the original purpose of non-intervention, which was avoiding war and conquest. ${ }^{88}$ As he put it, this was 'Intervention on the wrong side; Intervention by all who chose, and are strong enough, to put down free movements of peoples against corrupt governments. It means cooperation of despots against peoples' ${ }^{89}$ Secondly, non-intervention was applicable only if all states were distinct nations, in which case 'the government must deal directly and alone with its people', with no foreign interference. ${ }^{90}$ But most states were not nations, and empires trampled on nations aspiring to freedom.

These two factors did not lead Mazzini to advocate military intervention. He allowed only for two exceptions to non-intervention: (1) to offset a previous intervention in support of despots, that is, counter-intervention; ${ }^{91}$ and (2) to intervene to stop massacres ('massacres of Christians'). ${ }^{92}$ In the first case he advocated mainly 'moral support' and a credible threat of counter-intervention by a powerful liberal nation in the hope that it would be sufficient to deter a despot from intervening. ${ }^{93}$

On intervention, including humanitarian intervention, he followed a middle path among Italians in the course of the long nineteenth century, between strict non-intervention, as advocated by jurists Mamiani, Pierantoni, Carnazza Amari and Cimbali, ${ }^{94}$ and collective intervention in humanitarian plights, as argued by Fiore and Cavaglieri (see chapter 4 ). He also followed another well known tendency of the Italian school of international law: advocacy of intervention to free an oppressed nation.

\section{J. S. Mill, non-intervention and intervention}

John Stuart Mill is classified today as a communitarian, especially given his stance on nationalism..$^{95}$ But if one takes into consideration other aspects of Mill's approach to international relations, such as his emphasis on 'the general prosperity of mankind' or international law as the protector of the weak, ${ }^{96}$ he appears more of a cosmopolitan or simply defies classification. ${ }^{97}$

Mill in discussing intervention made no reference to contemporary jurists, probably given his aloofness towards international law based on Austin's views (see chapter 4$).{ }^{98}$ The international lawyers for their part returned the compliment 
by not mentioning Mill at all on intervention or non-intervention, with very rare exceptions, such as Bernard as regards intervention ${ }^{99}$ and a few others with regard to intervening in 'barbarous' regions.

Mill's main work on intervention is his 1859 essay 'A Few Words on NonIntervention', ${ }^{100}$ in which he makes a very strong case for non-intervention but an equally convincing case for intervention in several circumstances. This has led to confusion as to where he really stands and he has been criticized as 'ambivalent', ${ }^{101}$ and 'not at his most convincing' ${ }^{102}$ regarding the principle (non-intervention) he presumably, judging from the title, set out to defend.

References to non-intervention and intervention were also made by Mill in an earlier essay, 'The French Revolution of 1848 and Its Assailants' (1849), and in a forgotten article, 'The Spanish Question', published in 1837, which he had written together with a former army officer. ${ }^{103}$

The main rule of thumb to grasp Mill's overall position on non-intervention/ intervention is whether a movement striving for freedom is seeking independence from 'a foreign yoke' or is seeking to overthrow a 'native tyrant' and establish liberal democratic rule. In the first instance he advocates external intervention (starkly or hesitantly), while in the second he advocates strict non-intervention. ${ }^{104}$

Let us start with non-intervention. Mill was opposed to intervention in support of liberty, for a people will be better served if they 'are left to work out their own salvation'. ${ }^{105}$ At least five arguments can be identified in buttressing non-intervention. ${ }^{106}$

The first argument is uncertainty as to the outcome of intervention: 'there can seldom be anything approaching to assurance that intervention, even if successful, would be for the good of the people themselves'. ${ }^{107}$ The second argument is the readiness to wage a struggle despite the grave dangers involved. As he puts it: 'The only test possessing any real value, of a people's having become fit for popular institutions, is that they ... are willing to brave labour and danger for their liberation'. ${ }^{108}$ This is related to the argument of authenticity. ${ }^{109} \mathrm{He}$ asserts 'if they have not sufficient love of liberty to be able to wrest it from merely domestic oppressors, the liberty which is bestowed on them by other hands than their own, will have nothing real, nothing permanent'. ${ }^{110}$ In 'The Spanish Question' he puts it thus: 'The attempt to establish freedom by foreign bayonets is a solecism in terms. A government which requires the support of foreign armies cannot be a free government'. ${ }^{111}$ This leads us to a fourth argument: the danger of reversion to tyranny again, linked to one's own fighting. He argues that '[i]f a people ... does not value it [freedom] sufficiently to fight for it, and maintain it against any force which can be mustered ... it is only a question in how few years or months that people will be enslaved'. ${ }^{112}$ A related fifth point is that the virtues and feelings needed 'for maintaining freedom' spring up only 'during an arduous struggle to become free by their own efforts. ${ }^{113}$ In this context he makes a telling point: 'Men become attached to that which they have long fought for and 
made sacrifices for; they learn to appreciate that on which their thoughts have been much engaged'. ${ }^{114}$ This considerable insight on the part of the utilitarian philosopher (which Cobden, as we have seen, had also touched upon) tallies with the findings of today's cognitive psychology. As Leon Festinger has put it: 'Rats and people come to love the things for which they have suffered'. ${ }^{115}$ According to Morton Deutsch, presumably they do so in order to reduce the dissonance induced by the suffering, and their method of dissonance reduction is to enhance the attractiveness of the choice which led to their suffering: only if what one chose was really worthwhile would all of the associated suffering be tolerable'. ${ }^{116}$

The emphasis of Mill on a people's ability to use force successfully for liberation has been criticized as a social Darwinian (actually crude Spencerian ${ }^{117}$ ) 'survival of the fittest,, ${ }^{118}$ although Mill was not a social Darwinist. Walzer claims that this accusation, though not wide of the mark, is unfair to Mill, 'for it was precisely Mill's point that force could not prevail, unless it was reinforced from the outside over a people ready "to brave labor and danger"'. ${ }^{119}$ Anthony Ellis attributes Mill's stance to his belief 'that a people will be hard to oppress for long, once they have set their minds on freedom'. ${ }^{120}$

Now let us present the other side of the coin, intervention. Commentators have identified various exceptions, ranging from only two (Walzer) to as many as seven (Doyle). From Mill's at times convoluted presentation, we have identified five instances where Mill's non-intervention principle can be overcome in favour of its opposite, intervention: (1) in relations with 'barbarians', (2) in order to offset a previous counter-revolution by an external party against a people fighting against foreign rule, (3) in a struggle against a foreign yoke, (4) in protracted civil wars and (5), subsumed under civil war, stopping 'severities repugnant to humanity'.

Regarding the first instance, Mill subscribed to the nineteenth-century distinction between 'civilized' and 'barbarous' peoples (see chapter 3) and claimed that '[d] espotism is a legitimate mode of government in dealing with barbarians, provided the end be their improvement'. ${ }^{21}$ According to Mill, 'barbarians will not reciprocate. They cannot be depended on for observing any rules' 122 and 'it is likely to be for their benefit that they should be conquered and held in subjection by foreigners'. ${ }^{123}$

Mill, like the great majority of his European contemporaries, was an apologist for conquest and colonialism, an example of 'imperial liberalism', ${ }^{124}$ and indeed perhaps presenting 'the most well-known liberal justification of empire'. ${ }^{125}$ But terms such as 'benign colonialism'126 or 'tolerant imperialism' ${ }^{\prime 27}$ are probably more appropriate for Mill and in this way one also avoids retrospective thinking. Mill criticized harsh colonial measures in India (and, nearer home, in Ireland) and advocated the participation of Indians at the highest levels of administration. ${ }^{128}$ Moreover, for him cultural differences were not innate but a result of upbringing and circumstances, which could be remedied by education, and he was criticized by racists for not adhering to their views. ${ }^{129}$ 
The second exception is counter-intervention against a struggle for freedom from foreign rule. As Mill puts it: ${ }^{130}$

Intervention to enforce non-intervention is always rightful, always moral, if not always prudent... It might not have been right for England (even apart from the question of prudence) to have taken part with Hungary in its noble struggle against Austria; although the Austrian Government in Hungary was in some sense a foreign yoke. But when ... the Russian despot interposed, and ... delivered back the Hungarians, bound hand and foot, to their exasperated oppressors, it would have been an honourable and virtuous act on the part of England to have declared that this should not be, and that if Russia gave assistance to the wrong side, England would aid the right.

With this we arrive at another exception, assistance to a national liberation movement if it is 'unable to contend successfully ... against the military strength of another nation much more powerful'. ${ }^{131}$ But, as we have seen, he hesitated when faced with the Hungarian uprising. ${ }^{132}$

Here one is faced with a dilemma. If 'A Few Words' is to be regarded as his last and definite word on this question, then one is left with his hesitation and could agree with Walzer's first reading of Mill: that the two go together, assistance to the secessionist movement cum counter-intervention ${ }^{133}$ and that intervention is warranted only when counter-revolution by an external party has taken place. ${ }^{134}$ Another option is not to prioritize 'A Few Words' but to take it together with 'Vindication', where he calls for intervention in support of those fighting, to prevent them 'from being crushed and trampled' by foreign conquerors. ${ }^{135}$

In 1865 , when campaigning for elections, he gave the clear impression that he supported intervention even without counter-intervention. ${ }^{136}$ Mill's overall thrust regarding nationality and national self-determination ${ }^{137}$ can also be brought in to buttress intervention in support of independence movements. Mill (like Mazzini) believed that democracy can function properly only in national states. This was the very opposite of the position taken by Lord Acton, who was of the view that national states lead to absolutism and discrimination against minorities within. ${ }^{138}$

It is also worth referring to what was understood at the time by the readers of and commentators on 'A Few Words'. As Georgios Varouxakis points out, all understood Mill to mean that intervention should be used only in exceptional circumstances and that one assists a liberation moment if another state has intervened to suppress its efforts; and Mill was content with this interpretation of his views. ${ }^{139}$

The fourth exception, protracted civil war, includes within it a fifth, our subject matter: humanitarian intervention. According to Mill in 'A Few Words' ${ }^{140}$

A case requiring consideration is that of a protracted civil war, in which the contending parties are so equally balanced that there is no probability of a speedy 
issue; or if there is, the victorious side cannot hope to keep down the vanquished but by severities repugnant to humanity, and injurious to the permanent welfare of the country. In this exceptional case it seems now to be an admitted doctrine, that the neighbouring nations, or one powerful neighbour with the acquiescence of the rest, are warranted in demanding that the contest shall cease, and a reconciliation take place on equitable terms of compromise.

In 'A Few Words' it is not clear whether he means military intervention or mediation. But the examples he provides are suggestive, such as the Battle of Navarino by the three powers during the Greek War of Independence. Mill is clearer in 'Vindication': if attempts at accommodation by third parties are not accepted, then they may intervene by force. ${ }^{141}$

Humanitarian reasons, even though subsumed under civil war, can be seen as one of the reasons for intervening. ${ }^{142}$ As for the non-intervention/intervention nexus, it would seem that Mill, in his two earlier works, was more in support of intervention. But by 1859 , as an older and more prudent man, he had his doubts; thus his views come out as they do, perplexing and tentative. But perhaps it is better this way and shows the agonizing dilemma involved until this very day: a very convincing case against intervening can be made, as well as an equally convincing case for intervening in humanitarian plights or internal wars.

\section{Notes}

1 P. Laberge, 'Humanitarian Intervention: Three Ethical Positions', Ethics and International Affairs, 9 (1995), 15.

2 M. Hoffman, 'Normative International Theory: Approaches and Issues', in A. J. R. Groom and M. Light (eds), Contemporary International Relations: A Guide to Theory (London: Pinter, 1994), 33.

3 For Kant's cosmopolitanism in the international relations literature, see $\mathrm{H}$. Bull, The Anarchical Society: A Study of Order in World Politics (New York: Columbia University Press, 1977), 25-6; M. Wight, 'An Anatomy of International Thought', Review of International Studies, 13:3 (1987), 223-4; T. Donaldson, 'Kant's Global Rationalism', in T. Nardin and D. R. Mapel (eds), Traditions of International Ethics (Cambridge: Cambridge University Press, 1992), 143-4; T. Mertens, 'Cosmopolitanism and Citizenship: Kant Against Habermans', European Journal of Philosophy, 4:3 (1996), 329-34.

4 For Mill as a communitarian, see C. Brown, International Relations Theory: New Normative Approaches (London: Harvester Wheatsheaf, 1992), 71; Hoffman, 'Normative International Theory', 33 .

5 Brown, International Relations Theory, 65.

6 For a more nuanced view regarding Kant's cosmopolitanism see F. H. Hinsley, Power and the Pursuit of Peace (Cambridge: Cambridge University Press, 1963), 62-80; A. Hurrell, 'Kant and the Kantian Paradigm in International Relations', Review of International Studies, 16:3 (1990), 183-205.

7 A. Franceschet, 'Kant, International Law, and the Problem of Humanitarian Intervention', Journal of International Political Theory, 6:1 (2010), 3-4. 
8 For a succinct presentation of the points raised by Kant in Perpetual Peace, see H. L. Williams, 'Back from the USSR: Kant, Kaliningrad and World Peace', International Relations, 20:1 (2006), 27-48.

9 I. Kant, 'Toward Perpetual Peace', in I. Kant, Practical Philosophy (Cambridge: Cambridge University Press, 1996), 319.

10 Ibid., 319-20.

11 Ibid., 319-20.

12 Williams, 'Back from the USSR', 37.

13 F. R. Tesón, 'The Kantian Theory of International Law', Columbia Law Review, 92:1 (1992), 67-8; Laberge, 'Humanitarian Intervention', 18.

14 See S. Axinn, 'Kant, Authority, and the French Revolution', Journal of the History of Ideas, 32:3 (1971), 179-92; L. W. Beck, 'Kant and the Right of Revolution', Journal of the History of Ideas, 32:3 (1971), 411-22; H. S. Reiss, 'Kant and the Right of Rebellion', Journal of the History of Ideas, 17:2 (1956), 179-92.

15 T. Mertens, 'War and International Order in Kant's Legal Thought', Ratio Juris, 8:3 (1995), 31 n.14; H. van der Linden, 'Kant: The Duty to Promote International Peace and Political Intervention', in Proceedings of the Eighth International Kant Congress, Memphis 1995 (Milwaukee: Marquette University Press, 1995), vol. II, 73; Franceschet, 'Kant, International Law, and the Problem of Humanitarian Intervention', 8; Williams, 'Back from the USSR', 31, 37-8.

16 Laberge, 'Humanitarian Intervention', 18.

17 All quoted in B. Orend, 'Kant's Ethics of War and Peace', Journal of Military Ethics, 3:2 (2004), 163.

18 Quoted in Hurrell, 'Kant and the Kantian Paradigm in International Relations', 201.

19 For Kant's complex position on war, see B. Orend, 'Kant's Just War Theory', Journal of the History of Philosophy, 37:2 (1999), 323-53; Orend, 'Kant's Ethics of War and Peace', 161-97; A. Pagden, The Enlightenment and Why It Still Matters (New York: Random House, 2013), 348-9. For Kant as a pacifist, see Mertens, 'War and International Order in Kant's Legal Thought', 296-314.

20 Axinn, 'Kant, Authority, and the French Revolution', 425.

21 Mertens, 'War and International Order in Kant's Legal Thought', 304; R. Tuck, The Rights of War and Peace: Political Thought and the International Order from Grotius to Kant (Oxford: Oxford University Press, 1999), 217-18.

22 Orend, 'Kant's Ethics of War and Peace', 167-9.

23 Mertens, 'War and International Order in Kant's Legal Thought', 311; T. Mertens, 'Kant's Cosmopolitan Values and Supreme Emergencies', Journal of Social Philosophy, 38:2 (2007), 227; Hurrell, 'Kant and the Kantian Paradigm in International Relations', 200-2; H. Williams, Kant and the End of War: A Critique of Just War Theory (Basingstoke: Palgrave Macmillan, 2012), 32, 130, 135.

24 Mertens, 'Kant's Cosmopolitan Values and Supreme Emergencies', 225-7; G. Reichberg, 'Just War or Perpetual Peace?', Journal of Military Ethics, 1:1 (2002), 30 and 30 fn.25; Hurrell, 'Kant and the Kantian Paradigm in International Relations', 200-2; Orend, 'Kant's Ethics of War and Peace', 169.

25 G. Cavallar, 'Commentary on Susan Meld Shell's “Kant on Just War and 'Unjust Enemies': Reflections on a 'Pleonasm'”, Kantian Review, 11 (2006), 117-24; van der Linden, 'Kant', 73-4.

26 See notes 32-7 below and the following: C. Bagnoli, 'Humanitarian Intervention as a Perfect Duty: A Kantian Argument', Nomos, 47 (2004), 1-29; S. M. Shell, 'Kant on Just 
War and "Unjust Enemies": Reflections on a "Pleonasm", Kantian Review, 10 (2005), 82-111; A. R. Bernstein, 'Kant on Rights and Coercion in International Law: Implications for Humanitarian Intervention', Jahrbuch für Recht und Ethik/Annual Review of Law and Ethics, 16 (2008), 57-100.

27 Tesón, 'The Kantian Theory of International Law', 54, 60-2, 67, 69-70.

28 C. R. Beitz, Political Theory and International Relations (Princeton: Princeton University Press, 1979), 82. This point had been made in the 1940 os by K. Loewenstein and C. J. Friedrich. See ibid., 82 n.35.

29 R. J. Vincent, Nonintervention and International Order (Princeton: Princeton University Press, 1974), 57.

30 Tesón, 'The Kantian Theory of International Law', 92.

31 Ibid., 93 (original emphasis). See also R. B. Lillich, 'Kant and the Current Debate over Humanitarian Intervention', Journal of Transnational Law and Policy, 6 (1997), 397.

32 Van der Linden, 'Kant', 73-4.

33 T. Hill, 'Kant and Humanitarian Intervention', Philosophical Perspectives, 23 (2009), 229 (original emphasis).

34 Ibid., 236.

35 Franceschet, 'Kant, International Law, and the Problem of Humanitarian Intervention', 4 .

36 Ibid., 8.

37 Ibid., 8-18.

38 See on this basic point Laberge, 'Humanitarian Intervention', 18.

39 Beitz, Political Theory and International Relations, 82 n.35.

40 Williams, Kant and the End of War, 118.

41 Laberge, 'Humanitarian Intervention', 18.

42 A. Pagden, 'Stoicism, Cosmopolitanism, and the Legacy of European Imperialism', Constellations, 7:1 (2000), 18.

43 Laberge, 'Humanitarian Intervention', 18.

44 Cavallar, 'Commentary on Susan Meld Shell's "Kant on Just War and Unjust Enemies”', 121.

45 Franceschet, 'Kant, International Law, and the Problem of Humanitarian Intervention', 11.

46 Williams, Kant and the End of War, 140. See on this point also Donaldson, 'Kant's Global Rationalism', 142-6.

47 Williams, Kant and the End of War, 130.

48 Ibid., 131, 133.

49 Beitz, Political Theory and International Relations, 76.

50 S. Avineri, Hegel's Theory of the Modern State (Cambridge: Cambridge University Press, 1972), 178.

51 Quoted in S. Avineri, 'The Problem of War in Hegel's Thought', Journal of the History of Ideas, 22:4 (1961), 468.

52 F. Tesón, Humanitarian Intervention: An Inquiry into Law and Morality (New York: Transnational Publishers, 1997) [1988], 55.

53 Tesón, Humanitarian Intervention, 59; K. R. Popper, The Open Society and Its Enemies, Volume II. The High Tide of Prophesy: Hegel, Marx, and the Aftermath (London: Routledge and Kegan Paul, 1945), 259.

54 S. B. Smith, 'Hegel's Views on War, the State, and International Relations', American Political Science Review, 77:3 (1983), 627. 
$55 \quad$ Ibid., 627.

56 F. Parkinson, The Philosophy of International Relations: A Study in the History of Thought (Beverly Hills: Sage, 1977), 78.

57 Quoted in ibid., 78.

58 Ibid., 79.

59 Quoted in Avineri, 'The Problem of War in Hegel's Thought', 464.

60 Smith, 'Hegel's Views on War, the State, and International Relations', 629-31; Popper, The Open Society and Its Enemies, 65, 69-70.

61 See H. G. ten Bruggencate, 'Hegel's Views on War', Philosophical Quarterly, 1 (1950), 58-60; Avineri, 'The Problem of War in Hegel's Thought', 463-74; Avineri, Hegel's Theory of the Modern State, 194-207; C. I. Smith, 'Hegel and War', Journal of the History of Ideas, 26:2 (1965), 282-5.

62 See Smith, 'Hegel's Views on War, the State, and International Relations', 624-32.

63 Ibid., 628-9.

64 For this insight we thank the Greek Hegel scholar Georges Faraklas.

65 Parkinson, The Philosophy of International Relations, 95, 97, 145; W. Olson and A. J. R. Groom, International Relations Then and Now (London: Routledge, 1991), 30; M. J. Smith, 'Liberalism and International Reform', in Nardin and Mapel (eds), Traditions of International Ethics, 205-6; S. Burchill, 'Liberal Internationalism', in S. Burchill and A. Linklater (eds), Theories of International Relations (Basingstoke: Macmillan, 1995), 36, 39; T. Dunne, 'Liberalism', in J. Baylis and S. Smith (eds), The Globalization of World Politics: An Introduction to International Relations (Oxford: Oxford University Press, 2001, 2nd edition) [1997], 166-7.

66 J. A. Hobson, Richard Cobden: The International Man (London: T. F. Unwin, 1919).

67 Olson and Groom, International Relations Then and Now, 30.

68 Hinsley, Power and the Pursuit of Peace, 96.

69 Ibid., 97.

70 C. Holbraad, The Concert of Europe: A Study in German and British International Theory 1815-1914 (London: Longman, 1970), 155; Smith, 'Liberalism and International Reform', $205-6$.

71 Vincent, Nonintervention and International Order, 46.

72 Quoted in ibid., 46.

73 Ibid., 47.

74 Holbraad, The Concert of Europe, 156.

75 Quoted in Vincent, Nonintervention and International Order, 53.

76 Quoted in ibid., 53.

77 Ibid., 53.

78 Ibid., 53.

79 Parkinson, The Philosophy of International Relations, 97; Brown, International Relations Theory, 605 .

80 M. Ceadel, 'Cobden and Peace', in A. Howe and S. Morgan (eds), Rethinking NineteenthCentury Liberalism: Richard Cobden Bicentenary Essays (Aldershot: Ashgate, 2006), 189-207.

81 Holbraad, The Concert of Europe, 155-6; A. Howe, 'Introduction', in Howe and Morgan (eds), Rethinking Nineteenth-Century Liberalism, 2-5, 14-16.

82 C. Brown, 'Human Rights', in Baylis and Smith (eds), The Globalization of World Politics, 605 .

83 J. Pitts, A Turn to Empire: The Rise of Imperial Liberalism in Britain and France (Princeton: Princeton University Press, 2005), 124-62. 
84 M. Wight, 'Mazzini', in M. Wight and B. Porter (eds), Four Seminal Thinkers in International Theory: Machiavelli, Grotius, Kant and Mazzini (Oxford: Oxford University Press, 2005), 102.

85 Ibid., 100-3; S. Recchia and N. Urbinati, 'Introduction', in S. Recchia and N. Urbinati (eds), A Cosmopolitanism of Nations: Giuseppe Mazzini's Writing on Democracy, Nation Building and International Relations (Princeton: Princeton University Press, 2009), 2.

86 Ibid., 21.

87 G. Mazzini, 'On Nonintervention (1851)', in Recchia and Urbinati (eds), A Cosmopolitanism of Nations, 213-18.

88 Vincent, Nonintervention and International Order, 59-60.

89 Mazzini, 'On Nonintervention', 214, 217.

90 Ibid., 214-15.

91 Ibid., 216.

92 Ibid., 216-17.

93 Recchia and Urbinati, 'Introduction', 27. See also G. Mazzini, 'The European Question: Foreign Intervention and National Self-Determination', in Recchia and Urbinati (eds), A Cosmopolitanism of Nations, 195.

94 On Eduardo Cimbali, see E. Stowell, Intervention in International Law (Washington, DC: John Byrne and Co., 1921), 477.

95 Brown, International Relations Theory, 71, 73-5; Hoffman, 'Normative International Theory', 33 .

96 See K. E. Miller, 'John Stuart Mill's Theory of International Relations', Journal of the History of Ideas, 22:4 (1961), 499-501, 504.

97 Varouxakis regards Mill as an advocate of 'cosmopolitan patriotism', as he calls it. See G. Varouxakis, 'Cosmopolitan Patriotism in J. S. Mill's Political Thought and Action', in N. Urbinati and A. Zakaras (eds), J. S. Mill's Political Thought: A Bicentennial Reassessment (Cambridge: Cambridge University Press, 2007), 277-97.

98 See his comments in J. S. Mill, 'The French Revolution of 1848 and Its Assailants', Westminster and Foreign Quarterly Review, 51 (April 1849), 28. Reprinted as 'Vindication of the French Revolution of February 1848, in Reply to Lord Brougham and Others', in J. S. Mill, Dissertations and Discussions (London: Longmans, Green, Reader and Dyer, 1867), vol. II, 335-410 (henceforth 'Vindication').

99 M. Bernard, On the Principle of Non-Intervention. A Lecture Delivered in the Hall of All Souls College, December MDCCCLX (Oxford: J. H. and J. Parker, 1860), 3.

100 J. S. Mill, 'A Few Words on Non-Intervention', Fraser's Magazine, 6o (December 1859), reprinted in Mill, Dissertations and Discussions, vol. III, 153-78 (henceforth 'A Few Words').

101 A. Ellis, 'Utilitarianism and International Ethics', in Nardin and Mapel (eds), Traditions of International Ethics, 166.

102 M. Levin, J. S. Mill on Civilization and Barbarism (London: Routledge, 2004), 49.

103 J. S. Mill, 'The Spanish Question', London and Westminster Review, 5 (July 1837), 165-94. We thank Georgios Varouxakis for this information. Mill wrote the theoretical parts of this article, which dovetail with his statements on non-intervention and intervention in the other two essays.

104 M. Walzer, 'Mill's “A Few Words on Non-Intervention”: A Commentary', in Urbinati and Zakaras (eds), J. S. Mill's Political Thought, 352.

105 Beitz, Political Theory and International Relations, 84-6; M. Walzer, 'The Rights of Political Communities', in C. R. Beitz et al. (eds), International Ethics (Princeton: Princeton University Press, 1985), 178-9; Ellis, 'Utilitarianism and International Ethics', 166-7. 
106 Michael Doyle, in a perceptive article on Mill and Walzer, has come up with five points and we have taken on board three of them. See M. W. Doyle, 'A Few Words on Mill, Walzer, and Nonintervention', Ethics and International Affairs, 23 (2009), 352-5.

107 Mill, 'A Few Words', 173.

108 Ibid., 173.

109 See Doyle, 'A Few Words on Mill, Walzer, and Nonintervention', 352-3.

110 Mill, 'A Few Words', 174.

111 Mill, 'The Spanish Question', 179.

112 Mill, 'A Few Words', 174.

113 Ibid., 175 .

114 Ibid., 175 .

115 Quoted in M. Deutsch, The Resolution of Conflict (New Haven: Yale University Press, 1973), 357 .

116 Ibid., 357.

117 J. A. Rogers, 'Darwinism and Social Darwinism', Journal of the History of Ideas, 33:2 (1972), 265-8, 276-80.

118 J. N. Moore, 'International Law and the United States' Role in Vietnam: A Reply', in R. Falk (ed.), The Vietnam War and International Law (Princeton: Princeton University Press, 1968), 431.

119 Walzer, 'The Rights of Political Communities', 179.

120 Ellis, 'Utilitarianism and International Ethics', 167.

121 Quoted in M. Tunick, 'Tolerant Imperialism: John Stuart Mill’s Defense of British Rule in India', Review of Politics, 68:4 (2006), 595.

122 Mill, 'A Few Words', 167.

123 Ibid., 167.

124 Pitts, A Turn to Empire, 126-52; S. Holmes, 'Making Sense of Liberal Imperialism', in Urbinati and Zakaras (eds), J. S. Mill's Political Thought, 319-46.

125 K. Mantena, 'The Crisis of Liberal Imperialism', in D. Bell (ed.), Victorian Visions of Global Order: Empire and International Relations in Nineteenth-Century Political Thought (Cambridge: Cambridge University Press, 2007), 118. See also E. P. Sullivan, 'Liberalism and Imperialism: J. S. Mill's Defense of the British Empire', Journal of the History of Ideas, 44 (1983), 599, 605-17; B. Jahn, 'Barbarian Thoughts: Imperialism in the Philosophy of John Stuart Mill', Review of International Studies, 31 (2005), 599-618.

126 Doyle, 'A Few Words on Mill, Walzer, and Nonintervention', 356, 363-5.

127 Tunick, 'Tolerant Imperialism', 586.

128 Sullivan, 'Liberalism and Imperialism', 611; Levin, J. S. Mill on Civilization and Barbarism, 41.

129 Sullivan, 'Liberalism and Imperialism', 610; G. Varouxakis, 'John Stuart Mill on Race', Utilitas, 10:1 (1998), 18-32.

130 Mill, 'A Few Words', 176-7.

131 Ibid., 176.

132 For this hesitation on the part of Mill, see: Walzer, Just and Unjust Wars (New York: Basic Books, 1977), 93; Laberge, 'Humanitarian Intervention', 23; Varouxakis, 'John Stuart Mill on Intervention and Non-Intervention', Millennium: Journal of International Studies, 16:1 (1997), 70-1.

133 Walzer, Just and Unjust Wars, 90.

134 G. Varouxakis, Liberty Abroad: J. S. Mill and International Relations (Oxford: Oxford University Press, 2013). 90. 
135 Mill, 'Vindication', 29.

136 Varouxakis, Liberty Abroad, 97.

137 See S. Grader, 'John Stuart Mill's Theory of Nationality: A Liberal Dilemma in the Field of International Relations', Millennium: Journal of International Studies, 14:2 (1985), 207-16; Georgios Varouxakis, Mill on Nationality (London: Routledge, 2002).

138 Grader, 'John Stuart Mill's Theory of Nationality', 211.

139 Varouxakis, Liberty Abroad, 92-4.

140 Mill, 'A Few Words', 172 (emphasis added).

141 Mill, 'Vindication', 29.

142 See Miller, 'John Stuart Mill's Theory of International Relations', 505, 507, 510; Holbraad, The Concert of Europe, 164-6; Vincent, Nonintervention and International Order, 55-6; Varouxakis, 'John Stuart Mill on Intervention and Non-Intervention', 59-60, 68-75; C. A. L. Prager, 'Intervention and Empire: John Stuart Mill and International Relations', Political Studies, 53:3 (2005), 629-30; Doyle, 'A Few Words on Mill, Walzer, and Nonintervention', 355-64; B. Jahn, 'Humanitarian Intervention - What's in a Name?', International Politics, 49:1 (2012), 51-2. 
Alexis Heraclides and Ada Dialla - 9781526125125 Downloaded from manchesterhive.com at $04 / 26 / 2023$ 02:19:38PM 